\title{
COVID-19: a trigger for severe thrombotic microangiopathy in a patient with complement gene variant
}

\author{
LARISA PINTE ${ }^{1,3}$, BOGDAN MARIAN SOROHAN ${ }^{2,3 *}$, ZOLTÁN PROHÁSZKA ${ }^{4}$, MIHAELA GHERGHICEANU ${ }^{3,5}$, \\ CRISTIAN BĂICUȘ ${ }^{1,3}$
}

\author{
${ }^{1}$ Colentina Clinical Hospital, Internal Medicine Department, Bucharest, Romania \\ ${ }^{2}$ Fundeni Clinical Institute, Department of Nephrology, Bucharest, Romania \\ ${ }^{3}$ Carol Davila University of Medicine and Pharmacy, Bucharest, Romania \\ ${ }^{4}$ Department of Medicine and Hematology, Research Laboratory Semmelweis University, Budapest, Hungary \\ ${ }^{5}$ Ultrastructural Pathology Laboratory, Victor Babeș National Institute of Pathology, Bucharest, Romania
}

\begin{abstract}
The evidence regarding thrombotic microangiopathy (TMA) related to Coronavirus Infectious Disease 2019 (COVID-19) in patients with complement gene mutations as a cause of acute kidney injury (AKI) are limited. We presented the case of a 23 -year-old male patient admitted with an asymptomatic form of COVID-19, but with uncontrolled hypertension and AKI. Kidney biopsy showed severe lesions of TMA. In evolution patient had persistent microangiopathic hemolytic anemia, decreased level of haptoglobin and increased LDH level. Decreased complement C3 level and the presence of schistocytes were found for the first time after biopsy. Kidney function progressively decreased and the patient remained hemodialysis dependent. Complement work-up showed a heterozygous variant with unknown significance in complement factor I (CFI) c.-13G>A, affecting the 5' UTR region of the gene. In addition, the patient was found to be heterozygous for the complement factor $\mathrm{H}(\mathrm{CFH}) \mathrm{H} 3$ haplotype (involving the rare alleles of c.-331C>T, Q672Q and E936D polymorphisms) reported as a risk factor of atypical hemolytic uremic syndrome. This case of AKI associated with severe TMA and secondary hemolytic uremic syndrome highlights the importance of genetic risk modifiers in the alternative pathway dysregulation of the complement in the setting of COVID-19, even in asymptomatic forms.
\end{abstract}

Key words: COVID-19, thrombotic microangiopathy, acute kidney injury, complement.

\section{INTRODUCTION}

Acute tubular injury is the most common cause for acute kidney injury (AKI) in patients with Coronavirus Infectious Disease 2019 (COVID-19), but thrombotic microangiopathy (TMA) is also recognized as an important histological finding for kidney damage [1]. The evidence regarding TMA related to COVID-19 patients with complement gene mutations are limited [2-4]. We report the case of a 23-year-old male with AKI and severe TMA associated with COVID-19 who had a heterozygous variant with unknown significance in complement factor I (CFI) gene and risk polymorphisms in complement factor $\mathrm{H}(\mathrm{CFH})$.

\section{CASE PRESENTATION}

A 23-year-old male patient was admitted due to persistent headache. A reverse transcription polymerase chain reaction test was positive for severe acute respiratory syndrome coronavirus 2(SARS-CoV-2), with no symptoms of respiratory tract. His medical history revealed uninvestigated and untreated hypertension from the age of 19, with repeated values of systolic blood pressure (BP) higher than $180 \mathrm{mmHg}$ and 2 episodes of hypertensive urgency in the last month. A routine evaluation performed 2 weeks before admission, showed a serum creatinine of $2.8 \mathrm{mg} / \mathrm{dl}$. The past value of creatinine, tested 8 months before, was in the normal range. On admission, oxygen saturation was $98 \%$ (room air) and initial physical examination was unremarkable, except a BP value of 150/65 $\mathrm{mmHg}$. Urinary volume was around 2,000 $\mathrm{ml} / \mathrm{day}$.

\section{Initial work-up}

A summary of the laboratory data is shown in Figure 1A. Initial work-up revealed mild lymphopenia, mild anemia, normal platelets count 
and elevated LDH, while $\mathrm{C}$ reactive protein, ESR and IL6 were within the normal range. Serum creatinine was $4.8 \mathrm{mg} / \mathrm{dl}$. Urinalysis indicated a proteinuria of $0.98 \mathrm{~g} /$ day and no RBCs.

Potential common endocrine and renovascular causes of secondary hypertension were ruled out. Renal ultrasonography revealed normal kidneys size. The patient had ECG and echocardiographic signs of left ventricular hypertrophy and normal cardiac function.

Immunological panel for ANA, SCL70, anti-dsDNA, c-ANCA, p-ANCA, anti-GMB antibodies, cryoglobulins, along with HIV and hepatitis B and C serology was negative. C3, C4 and immunoglobulin levels were within normal limits. Screening for antiphospholipid antibodies revealed positive lupus anticoagulant.

\section{Clinical course}

During follow-up, hemoglobin level and platelets count had decreased to $9.5 \mathrm{~g} / \mathrm{dl}$ and $125,000 / \mathrm{mcL}$, respectively. Also, at this time, haptoglobin level decreased $(0.1 \mathrm{~g} / \mathrm{L})$ and schistocytes were found on peripheral blood smear. C3 and C4 levels remained in the normal range. Kidney function evolution showed progressive increase of creatinine to $6.5 \mathrm{mg} / \mathrm{dl}$ associated with worsening of BP control (Figure 1B). He received anti-hypertensive medication, but no COVID-19 specific treatment.

A.

$\begin{array}{ccc}\text { Laboratory tests } & \text { Patient' values } & \text { Normal values } \\ \text { WBC }(/ \mu \mathrm{L}) & 7550 / \mu \mathrm{L} & 4000-11000 / \mu \mathrm{L} \\ \text { Lymphocytes }(/ \mu \mathrm{L}) & 1850 / \mu \mathrm{L} & 1500-4500 / \mu \mathrm{L} \\ \text { Hemoglobin } & 12.4 \mathrm{~g} / \mathrm{dl} & 11-15 \mathrm{~g} / \mathrm{dL} \\ \text { MCV }(\mathrm{fl}) & 86 / \mathrm{fl} & 80-100 / \mathrm{fl} \\ \text { Platelets }(/ \mu \mathrm{L}) & 160 \times 10^{3} / \mu \mathrm{L} & 150-450 / \mu \mathrm{L} \\ \text { CRP }(\mathrm{mg} / \mathrm{L}) & 1.96 \mathrm{mg} / \mathrm{L} & 0-5 \mathrm{mg} / \mathrm{L} \\ \text { ESR }(\mathrm{mm} / \mathrm{h}) & 10 \mathrm{~mm} / \mathrm{h} & 2-30 \mathrm{~mm} / \mathrm{h} \\ \text { IL-6 }(\mathrm{pg} / \mathrm{mL}) & 3.64 \mathrm{pg} / \mathrm{mL} & <7 \mathrm{pg} / \mathrm{mL} \\ \text { LDH }(\mathrm{U} / \mathrm{L}) & 484 \mathrm{U} / \mathrm{L} & 135-214 \mathrm{U} / \mathrm{L} \\ \text { Creatinine }(\mathrm{mg} / \mathrm{dl}) & 4.8 \mathrm{mg} / \mathrm{dl} & 0.5-0.9 \mathrm{mg} / \mathrm{dl} \\ \text { Urea }(\mathrm{mg} / \mathrm{dl}) & 165.2 \mathrm{mg} / \mathrm{dl} & 0-41 \mathrm{mg} / \mathrm{dl} \\ \text { Urinalysis } & & \\ \text { RBC } & N e g a t i v e & \\ 24 h \text { Proteinuria } & 0.98 \mathrm{~g} / 24 \mathrm{~h} & \\ \text { A/C } & 150 \mathrm{mg} / \mathrm{g} & \\ & & \end{array}$

B.
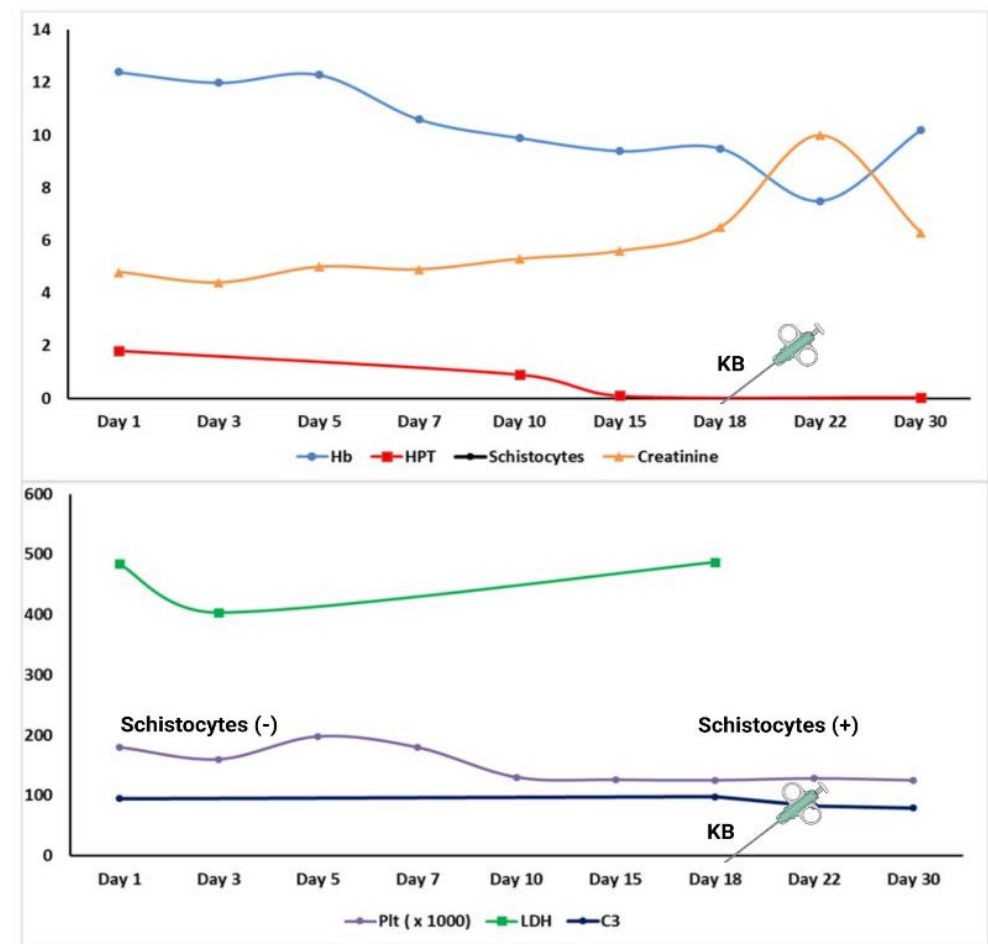

Figure 1. A. Relevant laboratory data at admission. B. Patient's evolution. Hb - Hemoglobin; HPT - Haptoglobin; Plt - Platelets; LDH - Lactate Dehydrogenase; KB - Kidney biopsy. 
A kidney biopsy $(\mathrm{KB})$ performed at day 18 confirmed the diagnosis of TMA (Figure 2). The specimen contained 12 glomeruli with ischemic changes. Immunofluorescence showed moderate fibrin positivity in the vessel walls, C3 and $\mathrm{IgM}$ strong positivity in the vessels and glomeruli. Light microscopy showed some ischemic-type glomeruli and others with capillary lumina occluded by fibrin thrombi. Tubulointerstitial lesions revealed tubules with hyaline casts. Arcuate and interlobular arteries had severely narrowed or occluded lumina, intimal cell proliferation with onion-skin lesion appearance, mucoid intimal hyperplasia and fibrinoid necrosis. Electron microscopy described electron-dense fibrin fibrils in the subendothelial area, subendothelial expansion with clear subendothelial space and swallowing intima with red blood cells, fibrin and macrophages.
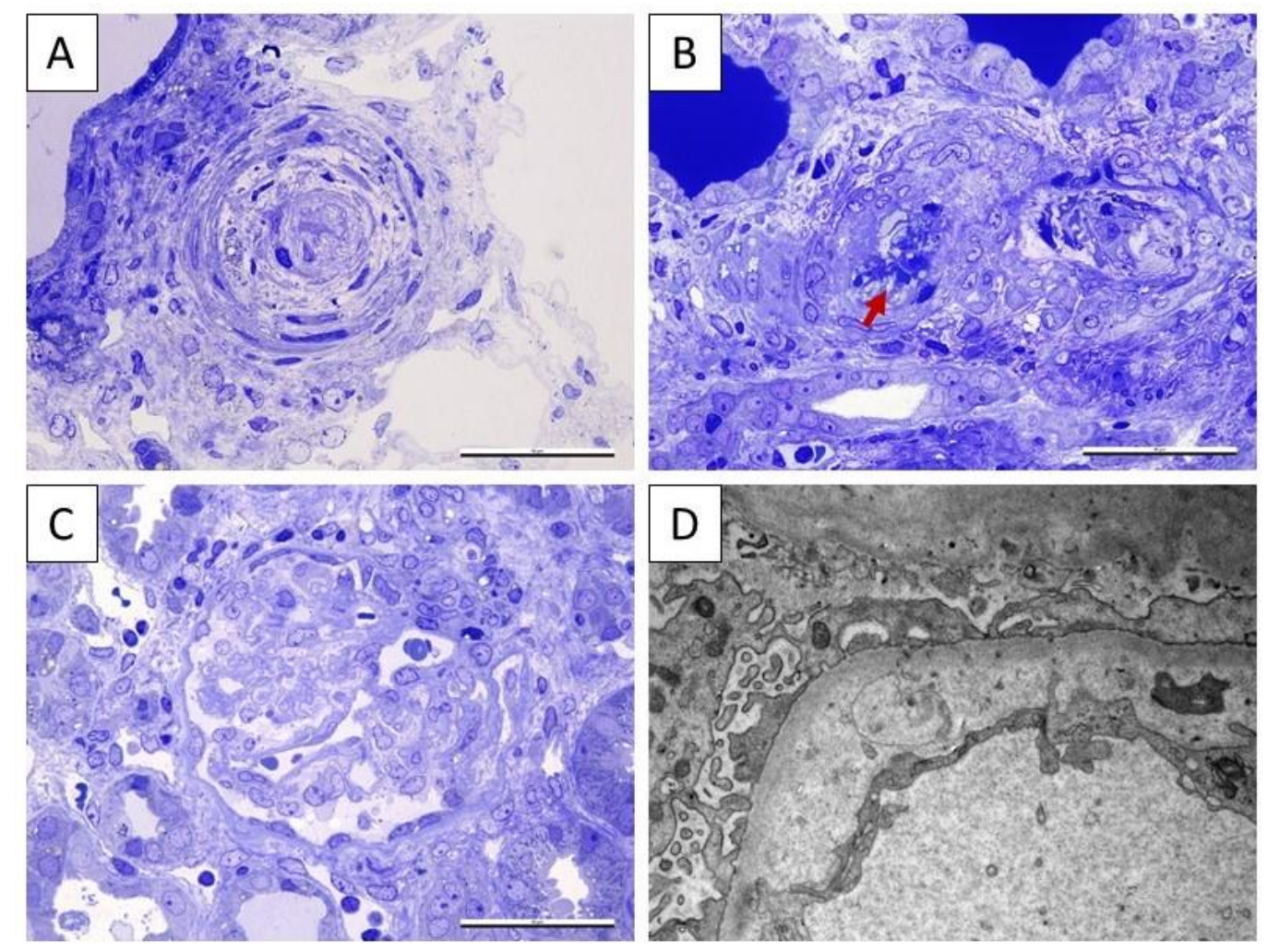

Figure 2. A: Light microscopy image of semithin plastic section showing an interlobular artery with intimal mucoid edema, small red blood cells fragments and severe occlusion of the vascular lumen (toluidine blue stain). B: Light microscopy image of semithin plastic section showing an interlobular artery with mucoid edema, a small focus of fibrinoid necrosis (red arrow) and red blood cells fragments (toluidine blue stain). C: Light microscopy image of semithin plastic section showing a glomerulus with ischemic changes with thickening and wrinkling of the basement membrane (toluidine blue stain). D: Electron microscopy photo showing the glomerular basement membrane with widening of the subendothelial space and diffuse podocyte foot process effacement.

\section{Evolution}

After KB the patient had persistent microangiopathic hemolytic anemia (MAHA), thrombocytopenia, decreased level of haptoglobin and increased LDH level. In addition, serum C3 level was decreased for the first time. Kidney function continued to decrease and creatinine became $10.7 \mathrm{mg} / \mathrm{dl}$ at day 22 , when he was initiated on hemodialysis. The patient was discharged after 30 days, remained dialysis dependent and was referred for kidney transplant evaluation (Figure 1B). Lupus anticoagulant repeated after 12 weeks had a positive value.
An extensive complement work-up was performed. The complement evaluation included ADAMTS13 activity, functional analysis for total complement classical and alternative pathway activity, quantification of individual complement components and regulators, measurement of complement activation markers (C5b-9 terminal complement pathway activity), autoantibodies (C3 nephritic factor, antibodies against $\mathrm{FH}$ and $\mathrm{FB}$ ) were available 5 months later. Biochemical analysis showed normal values for all analyzed parameters. Also, a genetic test was available later for the following genes: $\mathrm{C} 3, \mathrm{CFH}, \mathrm{CFI}, \mathrm{CFB}$, 
CD46, CFHR1-5 and THBD. DNA sequence of the whole coding regions of the complement tested genes was determined by direct DNA sequencing of polymerase chain reaction (PCR) products amplified from total genomic DNA. Genetic testing identified a heterozygous variant with unknown significance in $C F I$ c. $-13 \mathrm{G}>\mathrm{A}$, affecting the 5' UTR region of the gene. In addition, the patient was found to be heterozygous for the $\mathrm{CFH} \mathrm{H} 3$ haplotype (involving the rare alleles of c.-331C>T, Q672Q and E936D polymorphisms) reported as a risk factor of aHUS, and heterozygous for the rare allele of the p.Y402H polymorphism of $\mathrm{CFH}$, reported as a risk factor of developing dense deposit disease.

\section{DISCUSSIONS}

Initially, our patient presented with AKI, mild anemia, normal platelets levels, normal complement level, but with TMA lesions on kidney biopsy. During follow-up, patient developed MAHA, thrombocytopenia and decreased C3 level. Thus, a complete differential diagnosis of TMA was made after KB. Thrombotic thrombocytopenic purpura was excluded based on normal ADAMTS13 activity. Shiga toxin mediated hemolytic uremic syndrome (HUS) was ruled-out by the absence of Shigatoxin in the stool. Malignancy conditions were not found and drug-induced HUS was not applicable as the patient was not exposed recently to new drugs. Pregnancy-related or transplant-related HUS conditions were not applicable. Regarding autoimmune diseases associated HUS, the main differential diagnosis was with antiphospholipid syndrome. It is well known that antiphospholipid antibodies can arise transiently associated with various infections and critical illness.[5] In the general population the clinical relevance of isolated lupus anticoagulant positivity remains unclear, as does its link with thrombotic events in COVID-19 patients, despite the fact that LA was considered a frequent finding [6-8]. Based on patient's history of hypertension until COVID-19 event and the recent episodes of hypertensive urgencies, COVID-19 infection probably contributed to the worsening of a pre-existing hypertension by endothelial dysfunction damage.

TMA related to COVID-19 could occur due to the viral toxic direct effect on the endothelium, activation of alternative complement pathway or drug associated toxicity[9]. Yu et al. proposed a complement mediated mechanism in patients with COVID-19 and TMA. It seems that SARS-CoV-2 spike protein, subunit 1 and 2 , directly activates the alternative pathway of complement, which is responsible for diffuse endothelial injury and TMA[10]. A genetic predisposing condition regarding complement activation associated with a complement-amplifying event such as COVID-19 infection may represent the perfect scenario for a complement-mediated TMA development. The patient was found to be heterozygous for the $C F I$ rare variant of unknown significance (c.-13G>A), affecting the 5' UTR region of the gene, therefore it might have a role in the regulation of transcription. Normal plasma level of $C F I$ and the absence of complement alternative pathway dysregulation should be interpreted with caution due to the distance between infection and complement work-up. To our knowledge, this type of mutation has not been previously reported in association with TMA. However, this $C F I$ variant was reported in healthy individuals with a frequency of $0.4-2.8 \%$ based on the Exome Sequencing or 1000Genomes Projects[11] and was observed in aHUS patients in our laboratory (unpublished result). In addition, the patient was found to be heterozygous for the CFH H3 haplotype (involving the rare alleles of c.-331C >T, Q672Q and E936D polymorphisms), reported to be a risk factor for alternative pathway dysregulation and also a potential risk factor but not causative for aHUS[12,13]. The patient is a carrier of multiple common risk polymorphisms of alternative pathway dysregulation and even though these variants are risk modifiers, and not causative factors, we consider that in the setting of COVID-19 infection, they could be involved in complementmediated TMA. Based on our finding, the final diagnosis was considered a secondary HUS triggered by COVID-19. Also, aHUS could be a theoretically possible option. Noteworthy, in the present case we found severe TMA lesions associated with negative outcome of kidney function, despite the asymptomatic form of COVID-19. Due to the asymptomatic form, no disease specific treatment was used. An attempt at eculizumab treatment was not possible due to lack of availability and late diagnosis of thrombotic microangiopathy

\section{CONCLUSIONS}

We presented a case of severe biopsyproven TMA and secondary HUS in a patient with an asymptomatic form of COVID-19, who remained dialysis dependent and had genetic risk modifiers for complement alternative pathway. 
Date referitoare la microangiopatia trombotică (TMA) in COVID-19 la pacienții cu mutații ale genei complementului ca o cauză a injuriei acute renale (AKI) sunt limitate. Prezentăm cazul unui pacient de 23 de ani internat cu formă asimptomatică COVID-19, dar cu hipertensiune necontrolată și AKI. Biopsia renală a relevat leziuni severe TMA. Pacientul a prezentat anemie hemolitică microangiopatică, niveluri scăzute ale haptoglobinei și niveluri crescute ale LDH-ului. Niveluri scăzute ale complementului și schistocitele s-au observat după biopsia renală. Funcția renală a scăzut progresiv și pacientul a rămas dependent de hemodializă. Analiza genetică a demonstrat o variantă heterozigotă CFI c.-13G>A, afectând regiunea 5'UTR. In plus, pacientul era heterozigot pentru haplotipul H3 al CFH (ce implică alelele rare c.-331C>T, Q672Q și polimorfismul E936D), care și sunt raportate ca fiind factori de risc pentru sindromul hemolitic uremic. Acest caz de AKI asociat cu TMA sever și sindrom secundar hemotic uremic demonstrează importanța factorilor de risc genetici din calea alternativă de activare a complementului la pacienții asimptomatici COVID-19.

Correspondence to: Bogdan Marian Sorohan M.D., Assistant Professor, Department of Nephrology, Fundeni Clinical Institute, Fundeni Street No. 258, Bucharest 022328, District No. 2, Romania; E-mail address: bog-dan.sorohan@yahoo.com; Phone: +40740156198.

Authors' contributions: All authors equally contributed to data acquisition/analysis and drafting this manuscript. All authors reviewed the final version of this manuscript and agree with its submission to the journal.

Conflict of interest disclosure: The authors declared no potential conflicts of interest with respect to the research, authorship, and publication of this article.

Acknowledgments: We thank Dorottya Csuka, Katalin Szinyei-Merséné Marossy, Beáta Takács, Edina Szabó and Ágnes Szilágyi for genetic analysis, and coworkers of the Füst György Complement Diagnostic Laboratory for expert complement analysis and technical assistance.

\section{REFERENCES}

1. NG J.H., BIJOL V., SPARKS M.A., SISE M.E., IZZEDINE H., JHAVERI K.D. Pathophysiology and Pathology of Acute Kidney Injury in Patients With COVID-19. Adv Chronic Kidney Dis. 2020; 27(5):365-76.

2. VILLE S., LE BOT S., CHAPELET-DEBOUT A., BLANCHO G., FREMEAUX-BACCHI V., DELTOMBE C., et al. Atypical HUS relapse triggered by COVID-19. Kidney Int [Internet]. 2021; 99(1):267-8.

3. MAT O., GHISDAL L., MASSART A., AYDIN S., GOUBELlA A., BLANKOFF N., et al. Kidney Thrombotic Microangiopathy After COVID-19 Associated With C3 Gene Mutation. Kidney Int Reports. 2021;6(6):1732-7.

4. KAUFELD J.K., REINHARDT M., SCHRÖDER C., BRÄSEN J.H., WIECH T., BRYLKA P., et al. Atypical HUS triggered by infection with SARS-CoV2. Kidney Int Reports. 2021; 6(10):2709-2712.

5. ABDEL-WAHAB N., LOPEZ-OLIVO M.A., PINTO-PATARROYO G.P., SUAREZ-ALMAZOR M.E. Systematic review of case reports of antiphospholipid syndrome following infection. Lupus. 2016; 25(14):1520-1531.

6. HARZALlAH I., DEBLIQUIS A., DRÉNOU B. Frequency of lupus anticoagulant in COVID-19 patients. Journal of Thrombosis and Haemostasis. 2020; 18(10):2778.

7. DEVREESE K.M.J., LINSKENS E.A., BENOIT D., PEPERSTRAETE H. Antiphospholipid antibodies in patients with COVID-19: A relevant observation?. J Thromb Haemost. 2020;18(9):2191-201.

8. PINETON DE CHAMBRUN M., FRERE C., MIYARA M., AMOURA Z., MARTIN-TOUTAIN I., MATHIAN A., et al. High frequency of antiphospholipid antibodies in critically ill COVID-19 patients: a link with hypercoagulability?. Journal of Internal Medicine. 2021; 289(3):422-424.

9. TIWARI N.R., PHATAK S., SHARMA V.R., AGARWAL S.K. COVID-19 and thrombotic microangiopathies. Thromb Res. 2021; 202:191-198.

10. YU J., YUAN X., CHEN H., CHATURVEDI S., BRAUNSTEIN E.M., BRODSKY R.A. Direct activation of the alternative complement pathway by SARS-CoV-2 spike proteins is blocked by factor D inhibition. Blood . 2020 ;136(18):2080-9.

11. NHLBI Exome Sequencing Project (ESP) Exome Variant Server [Internet]. Available from: http://evs.gs.washington.edu/EVS/

12. CAPRIOLI J., CASTELLETTI F., BUCCHIONI S., BETTINAGLIO P., BRESIN E., PIANETTI G, et al. Complement factor $H$ mutations and gene polymorphisms in haemolytic uraemic syndrome: the C-257T, the A2089G and the G2881T polymorphisms are strongly associated with the disease. Hum Mol Genet. 2003; 12(24):3385-95.

13. NEUMANN H.P.H., SALZMANN M., BOHNERT-IWAN B., MANNUELIAN T., SKERKA C, LENK D, et al. Haemolytic uraemic syndrome and mutations of the factor $\mathrm{H}$ gene: a registry-based study of German speaking countries. $\mathrm{J}$ Med Genet. 2003; 40(9):676-81.

Received $24^{\text {th }}$ December 2021 